Article

\title{
Recent Precipitation Trends and Floods in the Colombian Andes
}

\author{
Álvaro Ávila ${ }^{1,2, *}$, Faisury Cardona Guerrero ${ }^{1}$, Yesid Carvajal Escobar ${ }^{1, *}$ and Flávio Justino ${ }^{2}$ \\ 1 Research group in Water Resources Engineering and Soil (IREHISA), Universidad del Valle, Cali, \\ Valle del Cauca 76001, Colombia; faisury.cardona@correounivalle.edu.co \\ 2 Department of Agricultural Engineering, Universidade Federal de Viçosa, Viçosa, MG 36570-900, Brasil; \\ fjustino@ufv.br \\ * Correspondence: alvaro.diaz@ufv.br (Á.Á.); yesid.carvajal@correounivalle.edu.co (Y.C.E.); \\ Tel.: (+57)-3164485361 (Y.C.E.)
}

Received: 13 December 2018; Accepted: 5 February 2019; Published: 22 February 2019

\begin{abstract}
This study aims to identify spatial and temporal precipitation trends by analyzing eight extreme climate indices of rainfall in the High Basin of the Cauca River in Southwestern Colombia from 1970 to 2013. The relation between historical floods and El Niño Southern Oscillation (ENSO) is also analyzed. Results indicate that in general, the reduction of precipitation, especially in the center of the basin with negative annual and seasonal trends in intensity indices, namely, the annual maximum 1-day precipitation amount (RX1day) and annual maximum 5-day precipitation amount (RX5day). Sixty-four percentage of the stations exhibit an increasing trend in September-October-November in the consecutive dry days. In December-January-February interval, positive trends in most of the stations is noted for total precipitation and for the number of wet days with rainfall greater than or equal to $1 \mathrm{~mm}$. The findings also show that sea surface temperature (SST) in the equatorial Pacific is statistically correlated $(r)$ with indices of extreme precipitation $(r \geq-0.40)$. However, the effect of ENSO is evident with a time lag of 2-3 months. These results are relevant for forecasting floods on a regional scale, since changes in SST of the equatorial Pacific may take place 2-3 months ahead of the basin inundation. Our results contribute to the understanding of extreme rainfall events, hydrological hazard forecasts and climate variability in the Colombian Andes.
\end{abstract}

Keywords: climate change; the Cauca River; climate variability; ENSO; extreme rainfall; trends

\section{Introduction}

Local intense rainfall events, as well as environmental alterations (deforestation and/or urbanization), may often trigger the incidence of hydrological hazards, such as floods, flash floods and landslides, especially in the tropical areas [1]. In Colombia, hydrological hazards mostly occur as a result of local heavy precipitation during the cold phase of the El Niño Southern Oscillation (ENSO), known as La Niña [2-6]. Hydrological basins located in the Andes are prone to hazards due to complex geographical terrain combined with spatial and temporal climate variability [5]. These events have a strong impact on a large portion of the local economy, since agriculture accounts for a significant amount of income generation $[7,8]$.

Between 1970 and 2013, floods affected about 16 million Colombians and claimed the lives of more than 3000 people, according to the Emergency Events Database (EM-DAT). In most cases, this is related to the "La Niña" that can lead to water-related hydrological hazards with catastrophic consequences for the livelihood of people and water resources. Indeed, the 2010-2011 La Niña affected 5.2 million people and caused 683 deaths and losses of more than US\$7.8 billion $[9,10]$. It is crucial to understand the causes of precipitation changes on global, continental, and regional scales and identify the link 
between these hydrological events and weather phenomena and/or climate variability at inter-decadal and inter-annual timescales [11-15].

The study of hydrometeorological threats, such as floods, flash floods, and landslides, requires a multidisciplinary approach to understanding the impact of climate variability and climate change on water pathways, water storage, and related hazards. Floods are the most frequent hydrological threats in the Colombia River Basins that is present along the Andes $[4,6,9]$. The increased frequency and intensity of extreme hydrometeorological events has become the main socio-environmental issue in the 21st century [13,16-19]. Therefore, efforts are needed to detect temporal changes in extreme rainfall and the main climate-associated mechanisms to mitigate the damage to society [20-22].

This study focuses on the High Basin of the Cauca River in Southwestern Colombia located in the Andes region. This region is susceptible to extreme precipitation events that cause flooding [6,23], affecting agricultural production sectors, thereby hampering regional and national economic development $[4,9,10]$. In lowlands, the natural land cover has been replaced by intensive agriculture, namely maize, sugar cane, and yucca, which are also cultivated for biofuel production [24]. More importantly, agriculture, livestock and the human population in the Colombian Andes have also increased exponentially over the last two centuries, with major peaks between the 1970s and 2000s [25]. Consequently, combined climate-topography-socio-economic factors create a highly vulnerable scenario for catastrophic events.

Currently, only a few studies have addressed long-term trends in precipitation extremes in the Colombian Andes [11,23,26,27]. In this study, 44 years (1970-2013) of daily precipitation data are used to analyze spatiotemporal trends of rainfall at an inter-annual time scale. Moreover, eight extreme precipitation indices in the High Basin of the Cauca River are analyzed. Specifically, the study explores the link between climate rainfall indices, historical floods, and ENSO, which can be used in association with climate indicators for flooding forecasting systems.

\section{Methodology}

\subsection{Study Area}

The High Basin of the Cauca River $\left(75^{\circ} 42^{\prime}-76^{\circ} 58^{\prime} \mathrm{W}, 2^{\circ} 06^{\prime}-05^{\circ} 2^{\prime} \mathrm{N}\right)$ rises in the Colombian Massif close to the Ecuadorian border and meanders along the Western and Central Andean Cordilleras. The basin extends over $18.111 \mathrm{~km}^{2}$ (Figure 1a). The mountains are higher $(4635 \mathrm{~m})$ in the east but lower $(891 \mathrm{~m})$ in the center and north, including the plains and hills.

This basin is a matter of concern in Colombia due to its important economic and ecological role as a natural resource of water for the La Salvajina Dam (hydropower plant), domestic water supply, and industrial and irrigation systems [28]. The population is approximately 4.5 million $(9.8 \%$ of the Colombian population in 2010), according to the National Administrative Department of Statistics. The High Basin of the Cauca River has been identified as the strongest potential leader in agriculture in Colombia, since it accounts for more than $90 \%$ of the sugarcane-planting area and sugar production [29], and trade and consumption of ethanol [30].

Flood events in the High Basin of the Cauca River occur due to extreme rainfall, drastic reductions in areas with natural forest [24,31], and the increased level of the population. For example, the city of Santiago de Cali (the most populous city in Southwestern Colombia) has regularly been vulnerable to river-based flooding. According to the Government of Colombia's National Administrative Department of Statistics (DANE, for its acronym in Spanish), the population of the city presented a strong growth of 31.538 people per year between 1985 and 2010, from 1.42 million to 2.24 million. This still raises concerns of land use changes due to increased agricultural activities and livestock, rural/urban migration and the expansion of urban edges, which imply that local geographic characteristics, anthropogenic factors and climate risks may lead to the onset of catastrophic floods. 

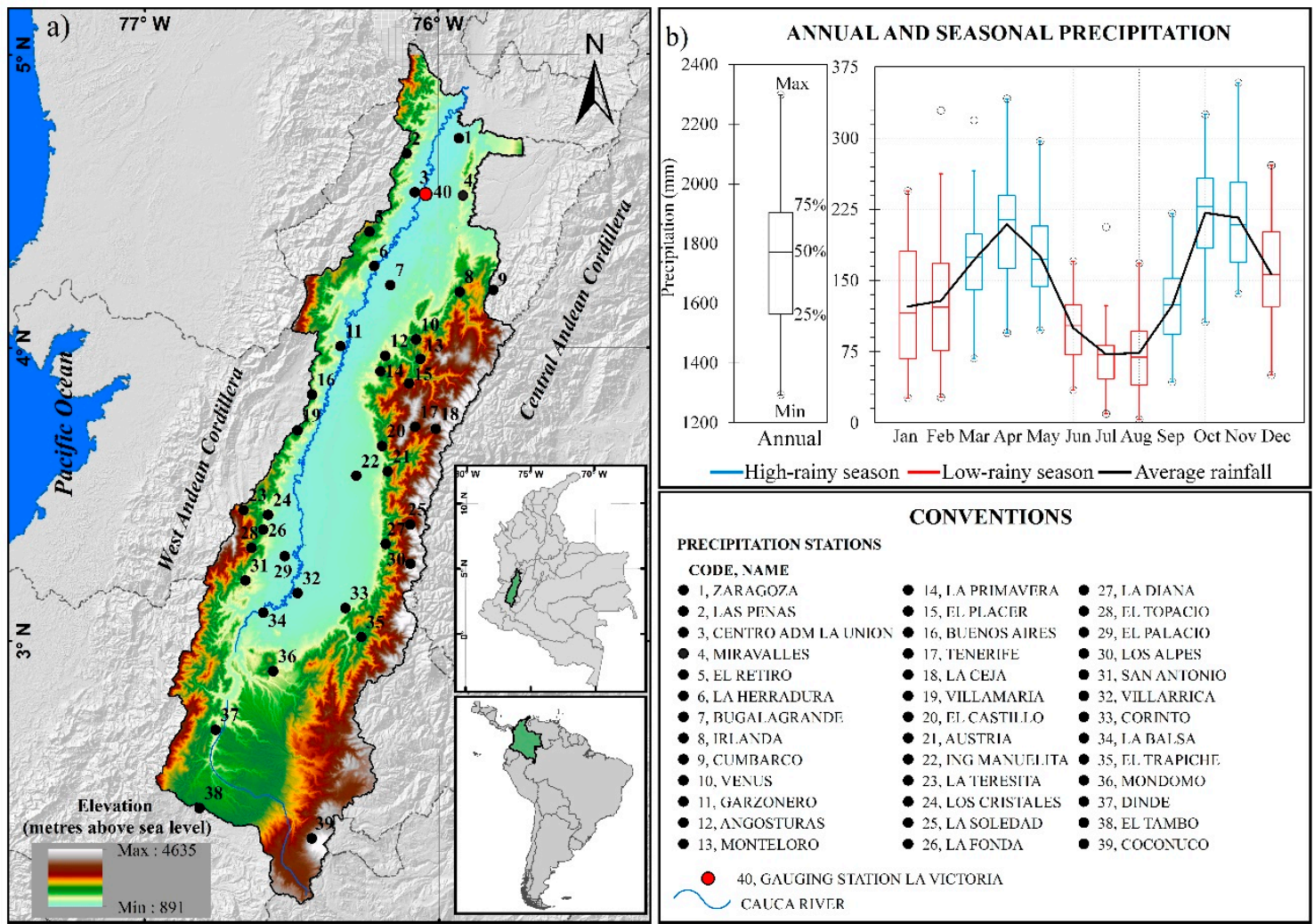

Figure 1. (a) Study area. Location of the High Basin of the Cauca River showing the pluviometric stations (black points) and location of the river gauging station (red point). (b) Annual and monthly variability of precipitation over the High Basin of the Cauca River over the 1970-2013 period. Source of cartography: Corporación Autónoma Regional del Valle del Cauca (CVC).

The hydroclimatology of the Colombian Andes is dominated by climatic mechanisms such as the latitudinal migration of the Intertropical Convergence Zone (ITCZ), associated with the trans-equatorial dynamics of the moisture induced by the eastern trade winds. The Chocó jet activity and the behavior of meso-scale convective systems also play a role as well [32,33]. Other hydroclimatological features in the area are discussed by [3,34-36]. The precipitation is affected by a double-ITCZ migration that flows from north to south and then back to north and goes across the geographic valley of the Cauca River twice a year (Figure 1b); this is a consequence of the semi-annual cycle of the march of the sun, and the circulation of the trade winds. For these reasons, there are two rainy seasons: March-April-May (MAM), and September-October-November (SON), which alternate with two reduced-rain seasons-December-January-February (DJF) and June-July-August (JJA). The total annual precipitation based on observational data over the 1970-2013 period is between 1294 and $2299 \mathrm{~mm}$ (Figure 1b).

\subsection{Data Quality Control and Homogeneity}

The data used in this study are provided by the Corporación Autónoma Regional del Valle del Cauca (CVC), based on historical daily precipitation from 108 rainfall stations. From these, only the stations with at least $90 \%$ of daily information between 1970 and 2013 were used. The dataset homogeneity and identification of possible biased records were investigated by performing RhtestV3 software developed and maintained by Wang and Feng [37] at the Climate Research Branch of Meteorological Service of Canada, a software running on $\mathrm{R}$ which are freely available online at http:/ / etccdi.pacificclimate.org/software.shtml. After homogeneity testing, only thirty-nine (39) rainfall stations met the established criteria to compute the extreme precipitation indices. 


\subsection{Extreme Precipitation Indices}

We used the RClimDex package developed by Zhang and Yang (2004) [38,39] at Climate Research Branch Environment of Canada. This package is a statistical tool for the R platform, proposed by the Expert Team on Detection and Climate Change Indices (ETCCDI; http: / / etccdi.pacificclimate.org/). In this study, eight precipitation-related indices were selected (Table 1). These indices are calculated at annual and seasonal scales (DJF, MAM, JJA, and SON). The seasonal analysis is justified by the marked inter-annual variability of precipitation, as shown above (Figure $1 \mathrm{~b}$ ). These extreme precipitation indices are also used to detect possible relationships between hydrological hazards and areas potentially vulnerable to catastrophic events $[13,15,22,40-42]$.

Table 1. Definition of indices selected for analysis of extreme precipitation recommended by the Expert Team on Climate Change Detection and Indices (ETCCDI).

\begin{tabular}{|c|c|c|c|}
\hline Index & Indicator & Definition & Unit \\
\hline PRCPTOT & $\begin{array}{l}\text { Annual total wet-day } \\
\text { precipitation }\end{array}$ & Total wet-day precipitation $\left(\mathrm{RR}^{*} \geq 1 \mathrm{~mm}\right)$ & $\mathrm{mm}$ \\
\hline RX1day & $\begin{array}{l}\text { Maximum 1-day } \\
\text { precipitation amount }\end{array}$ & Highest 1-day precipitation amount & $\mathrm{mm}$ \\
\hline RX5day & $\begin{array}{l}\text { Maximum 5-day } \\
\text { precipitation amount }\end{array}$ & $\begin{array}{l}\text { Highest 5-day precipitation amount in } \\
\text { consecutive days }\end{array}$ & $\mathrm{mm}$ \\
\hline R95p & Very wet days & $\begin{array}{l}\text { Precipitation due to very wet days } \\
\text { (>95th percentile) }\end{array}$ & $\mathrm{mm}$ \\
\hline NW & Number of wet days & Number of days for precipitation $\geq 1 \mathrm{~mm}$ & days \\
\hline $\mathrm{R} 30 \mathrm{~mm}$ & $\begin{array}{l}\text { Number of very heavy } \\
\text { precipitation days }\end{array}$ & Number of days for precipitation $\geq 30 \mathrm{~mm}$ & days \\
\hline CWD & Consecutive wet days & Maximum length of wet spell ( $R R \geq 1 \mathrm{~mm})$ & days \\
\hline CDD & Consecutive dry days & Maximum length of dry spell ( $\mathrm{RR}<1 \mathrm{~mm})$ & days \\
\hline
\end{tabular}

* $\mathrm{RR}$ is the daily rainfall $(\geq 1 \mathrm{~mm})$ amount on a wet day. Note: Indices are calculated using daily data precipitation, computed at the annual and seasonal scales in the 1970-2013 period.

The extreme rainfall indices can be divided in three categories (Table 1): (1) the intensity indices describe the amount of maxima (or maximum) precipitation in one day (RX1day) and maximum accumulated precipitation in 5 consecutive days (RX5day), respectively. The very wet days (R95p) represents the daily amount of precipitation that surpasses the 95th percentile value. The RX1day, RX5day and R95p were used to describe floods and flash flood risks (e.g., [13,41]); (2) frequency indices: the $\mathrm{R} 30 \mathrm{~mm}$ index represents the number of heaviest precipitation days and indicates the seasonal/annual count of days when the daily rainfall is greater than or equal to $30 \mathrm{~mm}$. The number of wet days (NW) counts the number of days with rainfall of $\geq 1 \mathrm{~mm}$; and (3) duration indices: the maximum number of consecutive wet days (CWD) and consecutive dry days (CDD). The PRCPTOT index is the seasonal/annual total wet-day precipitation with daily rainfall greater than or equal to $1 \mathrm{~mm}$. PRCPTOT does not necessarily have a direct relationship with the precipitation extremes but provides relevant information on the climatological aspects and in wet or dry periods [42].

Temporal trends of precipitation indices are examined by the Mann-Kendall (MK) trend test and calculated by the Sen slope estimator. The MK test $[43,44]$ is a wildly applied nonparametric method to characterize trends of extreme precipitation indices [11,14,18,45], whereas the nonparametric statistical test developed by Sen (1968) [46] is used to estimate the trend magnitude. These methods are less sensitive to outliers than parametric statistics [11,45]. A more detailed description of these methods can be found in Yue et al. [47]. Trends are considered to be statistically significant at the 5\% significance level.

\subsection{Regional Anomalies of Extreme Precipitation, ENSO and Flood Events}

Despite the small number of stations in the south $\left(2^{\circ} 06^{\prime}-3^{\circ} 0^{\prime} \mathrm{N}\right)$ and a larger coverage in the center $\left(3^{\circ} 0^{\prime}-4^{\circ} 0^{\prime} \mathrm{N}\right)$ and north $\left(4^{\circ} 0^{\prime}-05^{\circ} 2^{\prime} \mathrm{N}\right)$, the stations are found to be reasonably well distributed 
over the basin. The study area was divided into three regions according to the latitude: northern, central and southern. It is important to note that $12 \%, 72 \%$ and $15 \%$ of the basin's population are distributed in the north, central and south regions, respectively. We calculated the aggregate time series to evaluate the possible existence of large subregional asymmetries as well as exploring spatial coherence of natural variability in the precipitation extremes, ENSO, and floods events. This method has been widely used in the analysis of climate precipitation extremes $[13,17,26,48]$. The regional averaged anomaly series for each index was calculated using the following equation:

$$
x_{r, t}=\sum_{i=1}^{n_{t}}\left(x_{i, t}-\bar{x}_{i}\right) / n_{t}
$$

where $x_{r, t}$ is the regional averaged index at year $t ; x_{i, t}$ is the index $i$ at year $t ; \bar{x}_{i}$ is the 1970-2013 index mean at series and $n_{t}$ is the number of stations with data in year $t$. The regional series are expressed in millimeters (PRCPTOT, RX1day, RX5day, and R95p) and days (R30mm, NW, CDD, and DWD).

The impacts of ENSO on precipitation-related indices are also analyzed. The ENSO regimes are defined by the Niño 3.4, in line with previous studies by Poveda et al., Ávila et al., Morán-Tejeda et al., Maldonado et al. and Vicente-Serrano et al. [49-53]. The Niño 3.4 (0-10S, 90W-80W) characterizes Eastern Central Tropical Pacific Sea Surface Temperature (SST) anomalies. The series of the ENSO index over the 1970-2013 period are extracted from the National Oceanic and Atmospheric Administration website (NOAA; https:/ / www.esrl.noaa.gov/psd/data/climateindices/list/). To characterize the effect of SST of the Pacific Ocean on precipitation, Pearson's correlation test was performed between El Niño 3.4 index and the regional time series of the precipitation indices.

According to the U.S. Geological Survey, a flood is "an overflow of water onto lands that are used or usable by man and not normally covered by water. Floods have essential features: The inundation of land is temporary; the land is adjacent to and inundated by overflow from a river".

We explored the data from thirteen catastrophic floods, recorded since 1970, provided by the CVC and available in the "Hydrological Analysis of the Historical Flooding of the Cauca River" report [54], to analyze which is the pattern how extreme precipitation indices characterize the behavior of a flooding. The report is available at https://www.cvc.gov.co/. The CVC's report shows inundation maps (flooded area), dates and the maximum flow registered at the Victoria gauging station (Station ID 40; see the red point in Figure 1; further details in Appendix A). The flooding events occurring in the Cauca River after the onset of heavy rains are concentrated in flooded areas between $50 \mathrm{~km}^{2}-700 \mathrm{~km}^{2}$ (Table A1).

\section{Results and Discussion}

\subsection{Annual and Seasonal Extreme Precipitation Trends}

Trends and percentages of stations have been calculated for eight precipitation indices on annual (Figure 2a-i) and seasonal scales (Figures A1-A5), over the study area during the 1970-2013 period.

The total annual precipitation in wet days (PRCPTOT) has experienced positive trends in the north (Figure 2a) and negative trends over the center $\left(3^{\circ} 00^{\prime}-04^{\circ} 0^{\prime} \mathrm{N}\right)$ and south $\left(2^{\circ} 06^{\prime}-3^{\circ} 00^{\prime} \mathrm{N}\right)$ of the basin. The seasonal analyses also demonstrate negative trends for the PRCPTOT index (Figure 3b-d). In MAM, $59 \%$ of stations show negative trends, with $59 \%$ in JJA and $69 \%$ in SON (Figures A2-A4). However, for DJF (Figure A1), positive trends predominated in $74 \%$ of the stations. In general, the PRCPTOT has decreased over the past four decades, in particular in the central region. These results suggest that precipitation is decreasing in particular for both rainy seasons (MAM and SON) and in the dry seasons (JJA). These results are in accordance with those obtained by Puertas et al. [27], who analyzed the rainfall trends at annual and seasonal timescales in the 1975-2006 period. Differences between the current study and Puertas et al. [27] appear in the seasonal analyses. Puertas et al. [27] found statistically significant positive trends for DJF and SON, whereas in our study, this is true only for DJF where the positive trends predominated in $74 \%$ of the stations. Differences between these studies 
may arise from the longer time series and time intervals used in our analyses. We have investigated 12 years more than Puertas et al. [27] which indeed modifies the characteristics of the trends.

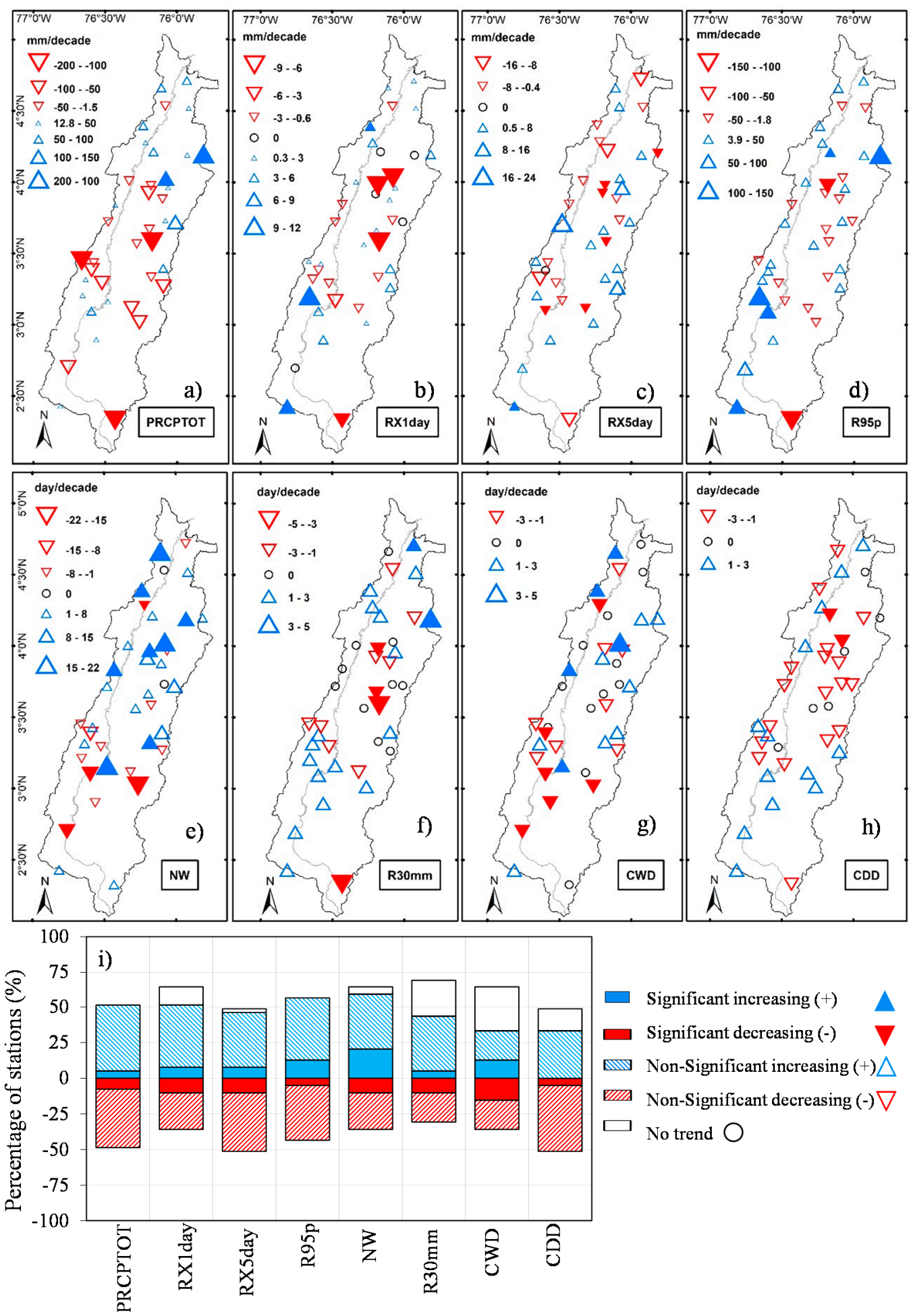

Figure 2. Spatial distribution of linear trends for annual precipitation indices: (a) PRCPTOT, (b) RX1day, (c) RX5day, (d) R95p, (e) NW, (f) R30mm, (g) CWD (h) CDD and (i) Percentage of stations with positive, negative and no change trends, out of the total stations examined over the Cauca River High Basin over the 1970-2013 period. Upward (downward) triangles refer to positive (negative) trends. Saturated triangles indicate trends significant at a $5 \%$ level and circles indicate no change trends. 


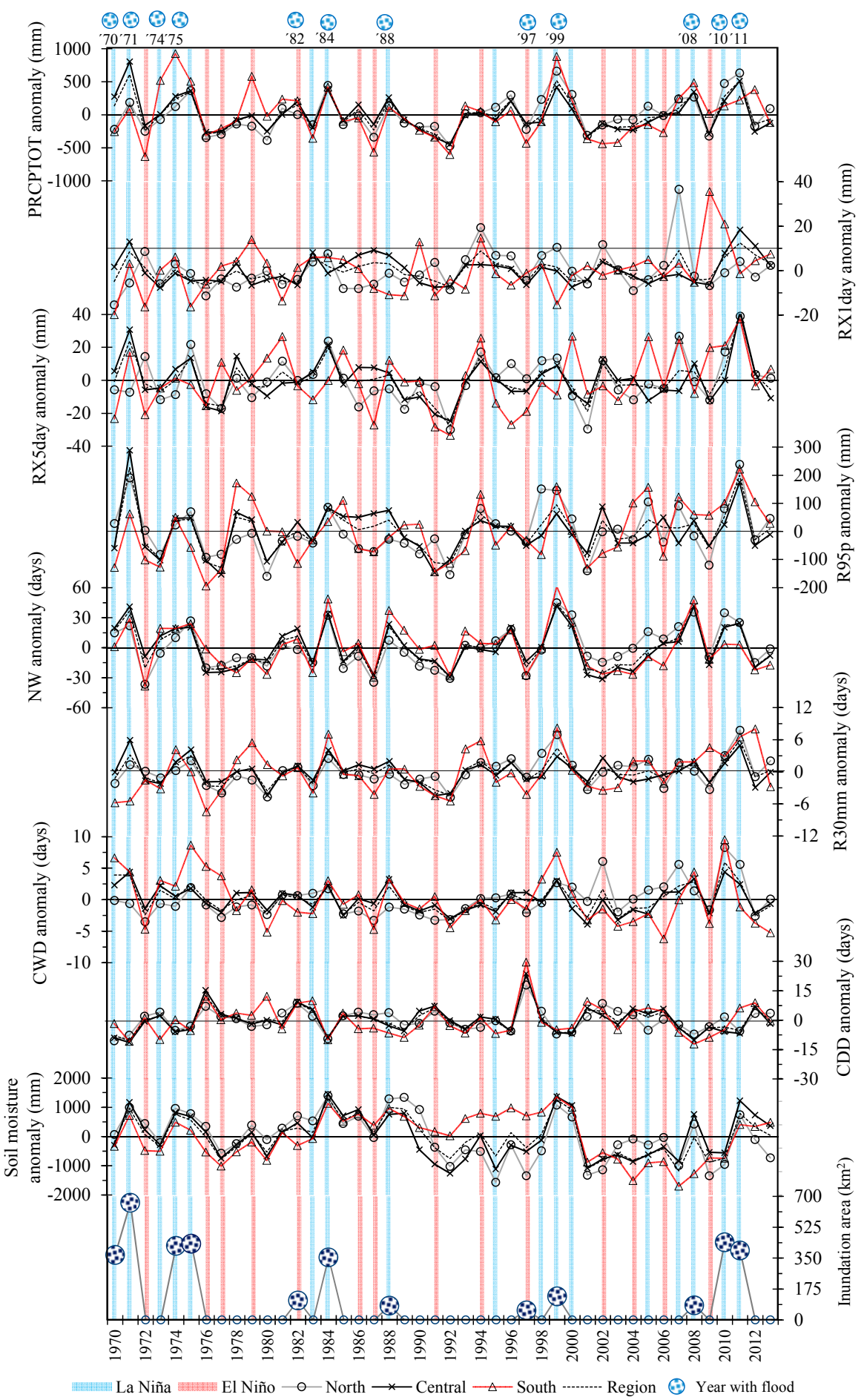

Figure 3. Temporal evolution of the anomalies for annual precipitation indices over north, central and south regions in terms of PRCPTOT, RX1day, RX5day and R95p, NW, R30mm, CDW and CDD. La Niña and El Niño occurrences are displayed by the vertical blue and red bars, respectively.

Celleri et al. [55] detected significant positive trends in rainfall over the Equatorial Andean for DJF and MAM, and negative tendency for JJA, from 1963 to 1993. Casimiro et al. [56] found similar seasonal trends over the Peruvian Andes for the 1965-2007 interval. In general, previous studies corroborate the generalized trend of increased precipitation for DJF (Figure A1), and decreased precipitation for JJA and SON results (Figures A3 and A4, respectively), which support our findings with the exception of MAM (Figure A2). 
On the annual scale, the negative trend of PRCPTOT is consistent with the results of Skansi et al. [11], who determined local trends of climate extremes indices on the annual scale for South America in the period 1969-2009. Likewise, this result agrees with those obtained by Aguilar et al. [26], who analyzed extreme precipitation indices for Central America and Northern South America over the 1961-2003. The PRCPTOT delivered negative trends over stations located in the lower and middle zones of our study area (Figure 2a).

The annual maximum 1-day precipitation amount (RX1day), annual maximum 5-day precipitation amount (RX5day), the number of days for precipitation of $\geq 30 \mathrm{~mm}$ (R30mm), and the maximum number of consecutive days (CWD) do not show similar trend characteristics (negative or positive) on the annual scale (Figure 2). Nevertheless, RX1day and RX5day were characterized by significant negative trends over the center of the basin, and the same happens at the seasonal level, except in DJF (Figures A1-A4). It is important to note that R95p and NW also show 56\% and 59\% of stations with positive trends, respectively, especially with significant upward trends in the center and north of the basin. The trends of R95p in the central region indicate that although PRCPTOT has been decreasing, the maximum events of rain have become more intense, especially if these tendencies correspond to the same stations $(19,22,24,26$ and 30). The NW delivers positive trends in DJF and MAM which increased by $69 \%$ and $54 \%$, respectively. It is important to note that the R30mm has shown no change of rainfall in most stations during all seasons. Similarly, CWD demonstrates in DJF and JJA that 54\% and $62 \%$ of the stations do not experience trends, respectively, with the exception of SON, with a general negative trend.

Additionally, RX1day, RX5day and R95p show positive trends, specifically in DJF and MAM (Figures A1 and A2). This is important because intense rainfall has been the main factor in the generation of historical flood of the Cauca River (Enciso, Carvajal, and Saldoval, 2016). Additionally, in these seasons, the maximum peaks in the flow of the Cauca River during floods have been presented (Table A1). In addition, these indices have statistically significant ( $p$ value $<0.05$ ) positive trends in the northern region, except for R95p that presents this type of trends in the southwest region, particularly in DJF. The positive trends of RX1day, RX5day and R95p in the north and south of the basin, at annual and seasonal levels, are important because it is where the sub-basins are located that contributed to the maximum flow of the historical floods of the Cauca River.

Skansi et al. [11] and Aguilar et al. [26] show positive trends on the annual scale for PRCPTOT, RX1day, RX5day and R95p, which is in line with our results in the northern region (Figure 2). However, this is not true in all cases for the center and south, where for example the PRCPTOT decreases. Our results provide an update of the extreme precipitation indices for the region, which were previously determined by Cardona et al. [23] during 1982-2011 on the annual scale in two Andean sub-basins of Cauca River Basin, located in the southwest of the region. The results coincide for PRCPTOT and CWD with negative trends and for RX1day with a positive trend. Additionally, Cuartas et al. [57] shows indices of climatic extremes at a monthly level between 1998 and 2013 in the flat area of the Cauca River Basin, where PRCPTOT and RX5day had positive trends. Our results show decreasing trends for these indices in the same area. This can be explained by the difference in the evaluation period and the analysis scale.

\subsection{Regional Anomalies of Extreme Precipitation, ENSO and Flood Events}

In order to verify whether the extreme precipitation is related with ENSO flood events from 1970 to 2013, we evaluated the temporal evolution of annual precipitation indices and soil moisture, which are shown in Figure 3. The stronger events tend to occur during La Niña years (e.g., 1970-1971, 1999, and 2011). We have found that during La Niña years, the anomalies of the PRCPTOT, RX5day, R95p, R30mm and NW are positive and higher than those related to El Niño years (Figure 3; vertical blue and red bars). The disaster areas of the 1988, 1999 and 2008 were years dictated by precipitation anomalies related to La Niña, and show however the lowest recorded (less than $134 \mathrm{~km}^{2}$ ). This has occurred, because a year before the flood, the contribution of soil moisture was low and the non-homogenous 
behavior of total precipitation and extreme events in comparison with the floods of greater disaster area. For example, in 1987 and 1998, there were negative anomalies in all indices in the southern region and in soil moisture in the northern region. Equally, in 2007, soil moisture anomalies were negative in all regions.

It is interesting to note that the CDD play an important role in the magnitude of the floods due to its implication on soil moisture before the flood occurrence. At the annual scale, the CDD index shows negative trends in the central and northern regions (Figure 3). The CDD present a positive trend in SON in $64 \%$ of the stations (Appendix A). These results can be associated to the minimum occurrence of rainfall due to a decrease in the PRCPTOT, RX1day and NW in this season. It should be emphasized that, currently, this is the High Basin of the Cauca River rainy season (SON). Furthermore, the decreasing in precipitation (PRCPTOT) in SON can be changes in DJF patterns rainfall, while the unbalanced spatial-temporal distribution of rainfall can play an important role in the formation of flood disasters, mainly in DJF and MAM that present the maximum peaks in the flow (Table A1).

The CDD reflects positive anomalies between extreme precipitation indices and years with floods (Figure 3). Furthermore, the magnitude of anomalies of the longest dry periods are associated with the El Niño events. For instance, El Niño conditions are related to reduced precipitation in the High Basin of the Cauca River. In 1982 and 1997 (Figure 3), the excess precipitation was not sufficient to cause major floods, because the soil could not store most of the rain since it was particularly dry. Two of the strongest El Niños in the last century occurred in these years [58]. In the 12 months preceding floods (1982, and 1997), positive anomalies were identified for two extreme precipitation indices (PRCPTOT and NW). This may have influenced a gradual increase in soil moisture, reducing the infiltration basin capacity and thus leading to flooding.

Avila et al. [13] investigated the daily extreme precipitation events and their link to the number of flash floods in Southeastern Brazil and found statistically significant positive correlation coefficients between flash flood and extreme precipitation for RX1day $(r>0.49)$ and RX5day $(r>0.39)$. Using similar indices, $\mathrm{Wu}$ and Huang [41] demonstrated that maximum RX1day and RX5day values coincide with the years when floods occur. However, in the current investigation, the RX1day was the least significant index for indicating floods in the High Basin of the Cauca River, as shown in Figure 3.

Aiming to further explore the climatological evolution of floods on the study area, we examined the large-scale forcing of the ENSO index (Niño 3.4), and its effects on extreme rainfall indices on a monthly scale. Considering the delayed precipitation in response to the ENSO index, we used different time lags ( 1 lag $=1$ month). The maximum coefficients of the Niño 3.4 (Figure 4 ) and precipitation-related index have been found for the time lag of 2-3 months. The PRCPTOT, RX1day, RX5day, R95p, NW, R30mm and CWD demonstrated significant negative correlations for all three areas. Central and south regions reflects the highest values for 2-lag in the PRCPTOT, RX5day, NW and CWD ( $r \leq-0.45)$, whereas the lowest values were generally found in RX1day, R95p, and R30 mm $(\geq-0.40)$ over the north region. On the other hand, the CDD reflect maximum significant positive correlations in central and south areas for the 3-lag with values between 0.41 and 0.44 .

The Niño 3.4 index delivered negative correlations with seven precipitation indices, which indicates that they are out of phase in this region and have an indirect relationship with extreme precipitation events. Indeed, negative values of the Equatorial Pacific SST, on the other hand, increase rainfall events over the basin. According to Morán-Tejada et al. and Vicente-Serrano et al. [51,52], the index of 3.4 explains most of the rainfall in the equatorial mountainous region (the Andes). This is supported by the results discussed here, since the correlation coefficients are statistically significant for all extreme precipitation indices related to dry as well as very humid periods. 

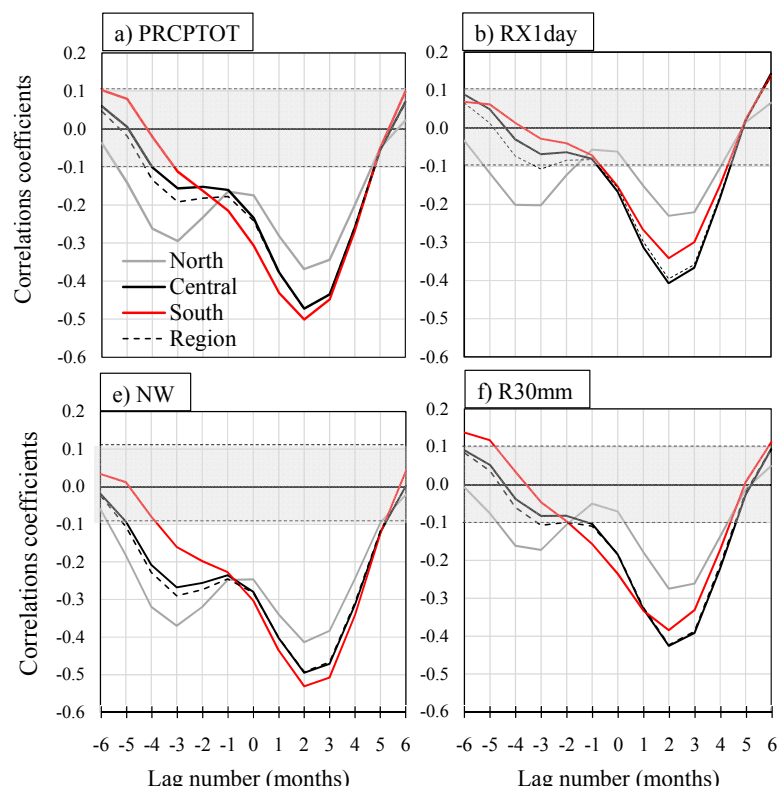
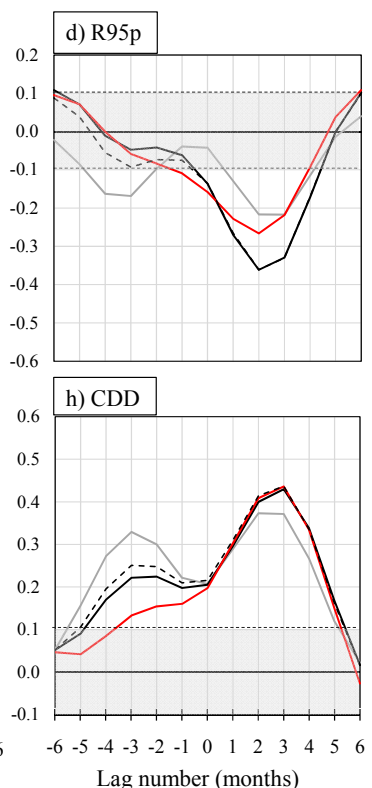

Figure 4. Pearson's correlation coefficients between Niño 3.4 and extreme monthly precipitation indices: (a) PRCPTOT, (b) RX1day, (c) RX5day, (d) R95p, (e) NW, (f) R30mm, (g) CWD and (h) CDD. The values in the gray zone indicate statistically insignificant correlations (at $p$-value $=0.05$ ). The $\mathrm{Y}$-axis refers to the correlation coefficient values and the $\mathrm{X}$-axis refers to the lag number (1 lag = 1 month).

In general terms, the north, central and south regions have similar temporal evolutions of extreme precipitation and highly correlated behavior within the index of 3.4 (Figure 4). In particular, central, southern and regional (region area: all stations) time series have analogues values of the anomalies and correlations coefficients (Figures 3 and 4). These results may have important implication in terms of preventing floods and being used in forecasting systems in key areas of the basin. In addition, the CVC and Enciso et al. [6,54] found that the highest frequency of flooding is concentrated in the center of the High Basin of the Cauca River $\left(3^{\circ} 0^{\prime}-4^{\circ} 0^{\prime} \mathrm{N}\right)$.

We explored the data from eleven catastrophic floods between 1970 and 2013 to investigate the ENSO influence (see Appendix A). Figure 5 only presents results for the central region because the majority of population is placed in this region. Further details of index anomalies over northern and southern regions are found in Appendix A (Figure A5). The most important factor to cause floods are the heavy precipitations associated with La Niña conditions, which generates the probability of elevated discharges of the Cauca River's and its tributaries rivers [6]. For this reason, the CDD index, which represents the maximum length of dry spell (dry events), is not included in this analysis.

Figure 5 shows the monthly evolution of seven precipitation extremes and the Niño 3.4 index before and after the flood event. Based on the $95 \%$ confidence interval (hatched area), it was observed that these indices are positive or close to zero for 3-11 months (phase 1) prior to the month with the peak flood discharge. At 0-2 months prior to the peak discharge (phase 2), during this phase, all extreme precipitation indices exhibit the maximum positive anomalies. This suggests that heavy precipitation (RX1day, R95p, and R30mm) and rainstorms (RX5day, NW, and CWD) contribute to the evolution and onset of the flooding. 


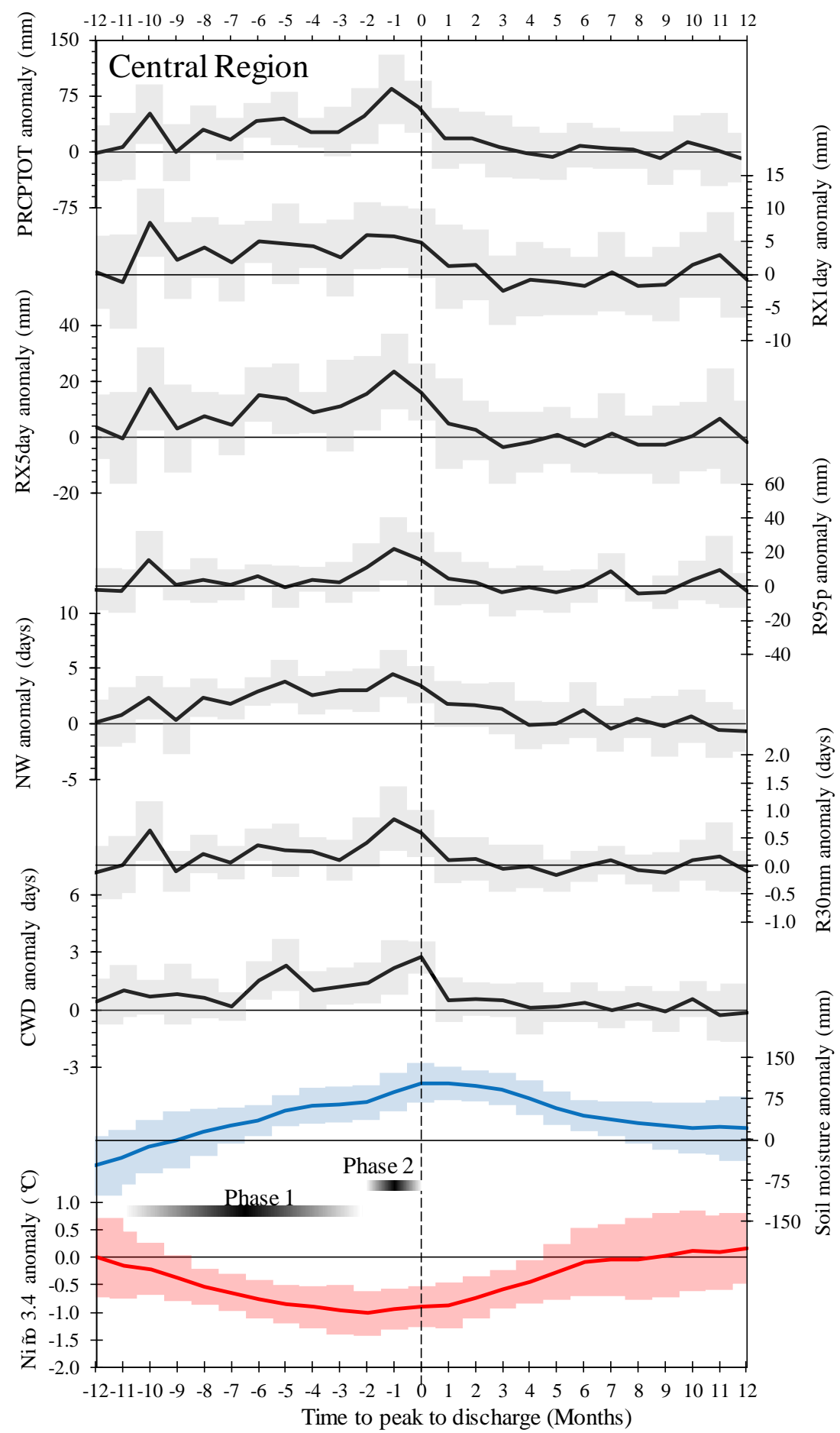

Figure 5. Index anomalies over the central region for PRCPTOT, RX1day, RX5day, R95, NW, R30mm, CDW, and soil moisture Niño 3.4 for floods that occurred under La Niña conditions $(\mathrm{n}=11)$ in relation to the time of the month with a peak discharge. The mean (line) and the $95 \%$ confidence interval (shaded bands) are shown for each index. The vertical dotted line refers to the peak of discharge; horizontal lines denote a zero anomaly for each index calculated.

The influence of climate features on extreme hydro-meteorological processes (such as floods) depends on the capability of understanding the role of abnormal pattern of atmospheric pressure, SST and soil moisture patterns [59,60]. An attempt is done here by evaluation of the synoptic hydro-meteorological conditions by constructing composite anomalies maps during the 1970-2013 
period (Figure 6), according to Welhouse et al. and Munoz and Dee [59,61]. With it being important to identify whether climate regimes, occurrence in far-off regions of interest may lead to floods in the Cauca River.

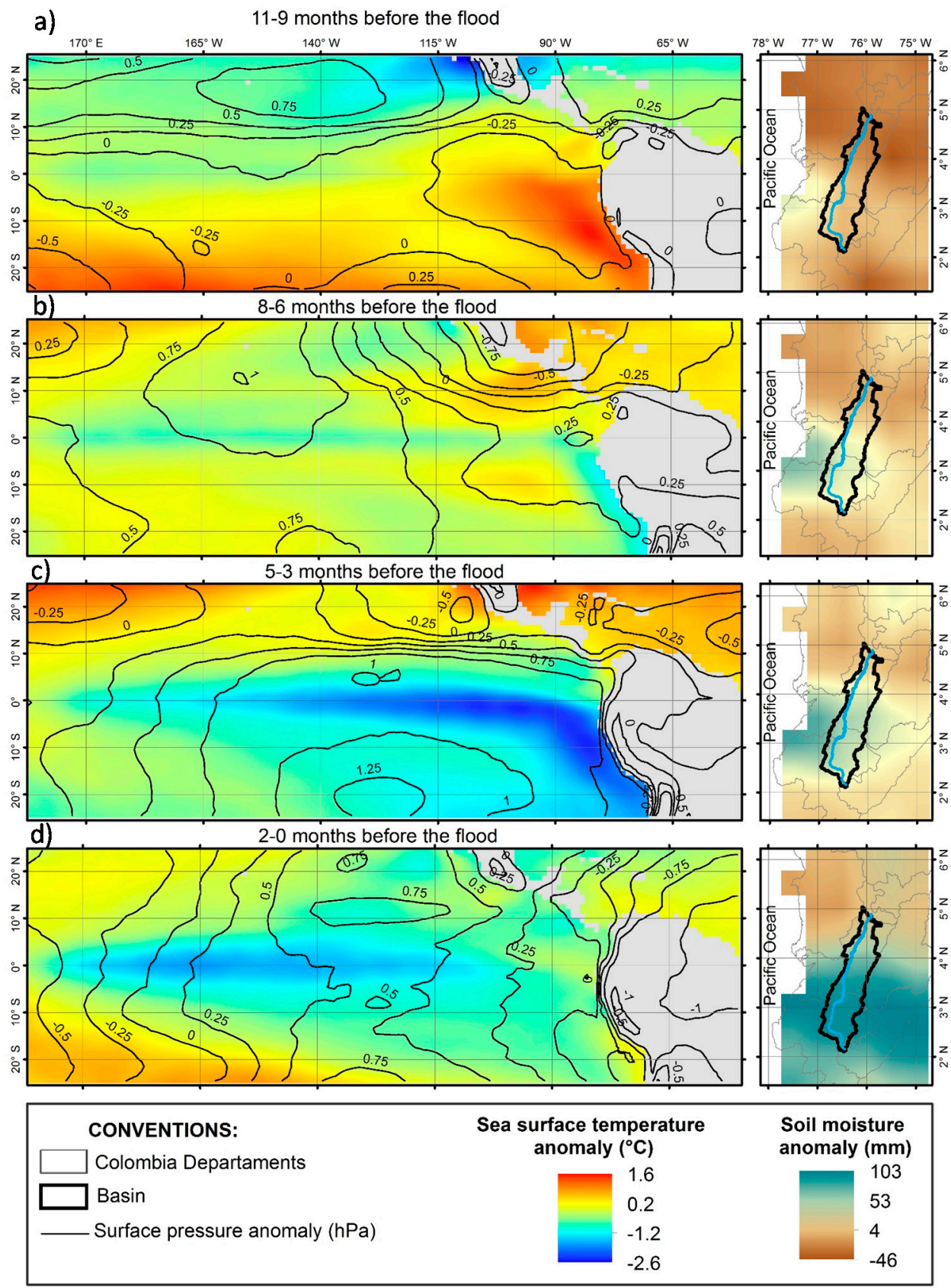

Figure 6. Composited anomalies of surface temperature over the Pacific sea surface, sea level pressure (contours), and soil moisture over the High Basin of the Cauca River: (a) 11-9 months, (b) 8-6 months, (c) 5-3 months, and (d) 2-0 months prior to floods events $(\mathrm{n}=11)$.

Henceforth, the monthly pressure data [62] at $1^{\circ} \times 1^{\circ}$ spatial resolution from the Princeton University Terrestrial Hydrology Research Group (http:/ / hydrology.princeton.edu/data.pgf.php) is used. The Centennial In Situ Observation-Based Estimates (COBE SST2) provides reliable monthly gridded datasets of global SST [63]. The COBE-SST2 $\left(1^{\circ} \times 1^{\circ}\right)$ dataset was downloaded from NOAA's official website (https://www.esrl.noaa.gov/psd/data/gridded/data.cobe2.html). The Climate Prediction Center (CPC; https:/ / www.esrl.noaa.gov/psd/data/gridded/data.cpcsoil.html) provides a monthly soil moisture dataset with a spatial resolution of $0.5^{\circ} \times 0.5^{\circ}[64]$. 
Figure 6 displays the composited anomalies of surface temperature, sea level pressure, and soil moisture over the over the tropical Pacific Ocean and Western South America. We calculated monthly subregional anomalies in the 12 months prior to the floods and calculated the mean and $95 \%$ confidence intervals for eight extreme precipitation climate indices.

Based on Figure 6, it is clear that by about 11-9 months prior to the floods, El Niño-like conditions dominate the equatorial Pacific, with much higher SST anomalies nearby the South America west coast. This pattern induces changes in surface pressure and negative SM, further leading to dry conditions in the Cauca basin (Figure 6a). The 8-6 month anomalies show a different pattern with lower SST anomalies and increased surface pressure along the South America margin. This pattern is intensified between 5 and 3 months before the flood, indicating the development of La Niña conditions. During this interval, remarkable changes are initiated, in particular in the central-south part of the Cauca River Basin which experiences a drop in surface pressure, and increased precipitation, which result in positive values of soil moisture (Figure $6 b, c)$. Two-Zero months before the flood event, negative anomalies of surface pressure dominate the north part of South America, in phase with substantial changes in soil water availability.

Evaluation of extreme precipitation indices delivered two phases of climatological evolution. The first phase is characterized by positive and high-magnitude extreme precipitation indices before the flooding. The second phase is characterized by the increase of soil moisture anomalies over the basin and saturated water storage over the period before the flood events.

These results imply that ENSO plays an important role in the flood area and magnitude, due to changes in precipitation extremes in a given year. Moreover, the results indicated that the highest negative values of the NIÑO 3.4 index occurs 3 months before the peak discharge (Figures 5 and 6). These results are fundamental in addressing the challenge of forecasting floods, since the changes in the Pacific SST are seen 3 months before the basin inundation. Similar results were found by Munoz and Dee [59] in the Lower Mississippi River floods (USA).

\section{Conclusions}

This study is the result of substantial data collection efforts, and it significantly builds upon previous studies $[23,27,61]$ by providing updated spatial and temporal coverage in the years leading up to 2013. The results in the study area show that the annual total precipitation on wet days (PRCPTOT) has decreased over the central and southern regions. Likewise, more than $59 \%$ of the stations showed decreasing trends in MAM, JJA and SON. However, an increase in total wet-days and the intensity of the extreme events (RX1day and RX5day) can be observed, as shown by a general increase in the events with days with rainfall of $\geq 1 \mathrm{~mm}$ (NW), for the DJF season, which is the dry interval.

In SON, decreased intensity, frequency and accumulated rainfall were observed (RX5day, NW and PRCPTOT), and this has generated the increase of CDD. It should be emphasized that, currently, this is the Cauca River rainy season.

Equally, JJA, which is a dry season, shows a decrease of accumulated and intensity rain and a decreased frequency of the days with rainfall, especially in the central region. Although it has not been our focus in the present study, the region has experienced a systematic increase in the number of vegetation fires, particularly in JJA [24,65], with substantial economic losses. The decreasing trends in precipitation indices pose a potential threat for the development of more erratic fires, due to the vulnerability of the region.

We found that the region El Niño $3+4$ shows significant correlation with the extreme precipitation indices. The SST field, principally at the time lag of 2-3 months, are highlighted, evidencing the strong relationship that ENSO has over the hydro-meteorology of Colombia. Consistent with these results, Córdoba-Machado et al [66] displayed through a Principal Component Analysis that a pattern based on global precipitation, mean temperature over land and SST of the ENSO regions (e.g. Niño 3, and Niño 4) is strongly linked to the hydro-meteorology of country. Nonetheless, the relationship between extreme precipitation indices and the Pacific SST is not considered in those studies, as has 
been evaluated in the present study. The understanding of precipitation extremes is necessary to undertake coordinated projects in order to alleviate the response of different productive sectors and reduce the threat to local populations. The occurrence of historical floods causes significant economic losses and strong stress on hydric resources. Changes in land use in the region have affected the natural capacity of the basin during extreme climate events.

In general terms, our results will benefit current and future studies on climate resilience for hydrological hazard forecasts on a regional scale, since the findings indicate that flooding events may be predicted by using a series of precipitation extreme indices, soil moisture and ENSO.

Author Contributions: Conceptualization, A.A. Y.C.E. and F.J.; Data curation, A.A. and F.C.G.; Formal analysis, A.A. and F.C.G.; Methodology, A.A. F.C.G. and F.J.; Project administration, F.C.G. and Y.C.E.; Writing - review \& editing, A.A., F.C.G., Y.C.E. and F.J.

Funding: This research received no external funding

Acknowledgments: We are thankful to the research groups IREHISA and Gesp-Group of Epidemiology and Population Health from the Universidad del Valle-Colombia. This work was supported by the Universidade Federal de Viçosa (Brazil), the Minas Gerais Research Foundation (FAPEMIG) and to the Coordination for the Improvement of Higher Education Personnel (CAPES). We also appreciate the Corporación Autónoma Regional del Valle del Cauca (CVC) for sponsoring the project: "Constructing a Conceptual Model for Recovering the Conservation Corridor and the Sustainable Use of Cauca River System in Its High Valley". We show gratitude to the Administrative Department of Science, Technology, and Innovation (COLCIENCIAS) in the framework of the program for Young Researchers and Innovators open call 2014 and the project "Regional analysis of the droughts related to climate variability for the implementation of adaptation strategies in agricultural production systems in Valle del Cauca".

Conflicts of Interest: The authors declare no conflicts of interest.

\section{Appendix A}

Table A1. Floods recorded at the gauging station at Victoria (Station ID 40; see the red point in Figure 1) in relation to ENSO events and flooded area in High Basin of the Cauca River.

\begin{tabular}{|c|c|c|c|c|c|c|c|c|}
\hline \multirow{2}{*}{\multicolumn{3}{|c|}{$\begin{array}{l}\text { Peak Stage Date } \\
\text { (Day/Month/Year) }\end{array}$}} & \multirow{3}{*}{$\begin{array}{c}\begin{array}{c}\text { Flow } \\
\left(\mathrm{m}^{3} / \mathrm{s}\right)\end{array} \\
1117\end{array}$} & \multirow{3}{*}{$\begin{array}{c}\begin{array}{c}\text { Flooded } \\
\text { Area }\left(\mathbf{k m}^{\mathbf{2}}\right)\end{array} \\
367.7\end{array}$} & \multicolumn{4}{|c|}{ Corresponding La Niña ${ }^{1}$} \\
\hline & & & & & \multicolumn{2}{|c|}{ Start Date } & \multicolumn{2}{|c|}{ End Date } \\
\hline 18 & November & 1970 & & & June & 1970 & December & 1971 \\
\hline 5 & April & 1971 & 1222 & 663.8 & June & 1970 & December & 1971 \\
\hline 24 & March & 1974 & 1219 & 419.1 & May & 1973 & June & 1974 \\
\hline 30 & December & 1975 & 1317 & 431.2 & September & 1974 & February & 1975 \\
\hline 18 & April & $1982^{2}$ & 972 & 110.0 & & & & \\
\hline 8 & November & 1984 & 1214 & 353.9 & September & 1984 & May & 1985 \\
\hline 8 & December & 1988 & 1148 & 128.8 & April & 1988 & April & 1989 \\
\hline 30 & January & $1997^{2}$ & 993 & 54.0 & & & & \\
\hline 2 & March & 1999 & 1166 & 133.7 & June & 1998 & February & 2001 \\
\hline 30 & November & 2008 & 1055 & 82.9 & July & 2007 & May & 2008 \\
\hline 4 & December & 2010 & 1202 & 440.2 & July & 2010 & March & 2011 \\
\hline 28 & April & & 1188 & & July & 2010 & March & 2011 \\
\hline 16 & December & $2011^{3}$ & 1205 & 393.2 & July & 2011 & January & 2012 \\
\hline
\end{tabular}

${ }^{1}$ Refers to a La Niña event that ended within a year prior to the major flood stage. ${ }^{2}$ Refers to an El Niño event, according to the Oceanic Niño Index (ONI) and its definition in Jan 2017. ${ }^{3}$ Information available only for the annual total area affected by the floods. 

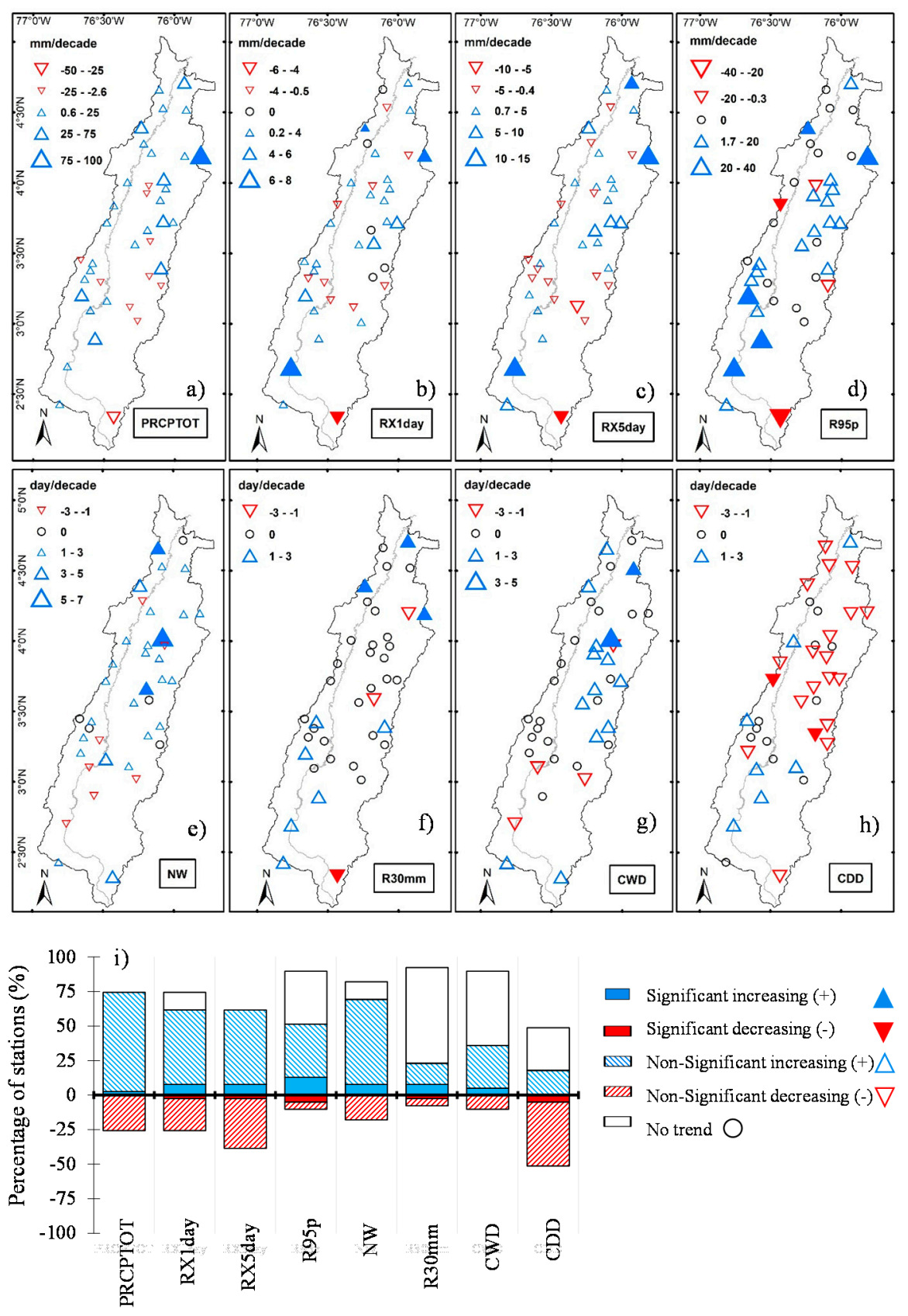

Figure A1. Spatial distribution of decadal trends for December-January-February (DJF). (a) PRCPTOT, (b) RX1day, (c) RX5day, (d) R95p, (e) NW, (f) R30mm, (g) CWD (h) CDD and (i) Percentage of stations with positive, negative and no change trends, out of the total stations examined over the Cauca River High Basin over the 1970-2013 period. Upward (downward) triangles refer to positive (negative) trends. Saturated triangles indicate trends significant at the $5 \%$ level and circles indicate no change trends. 

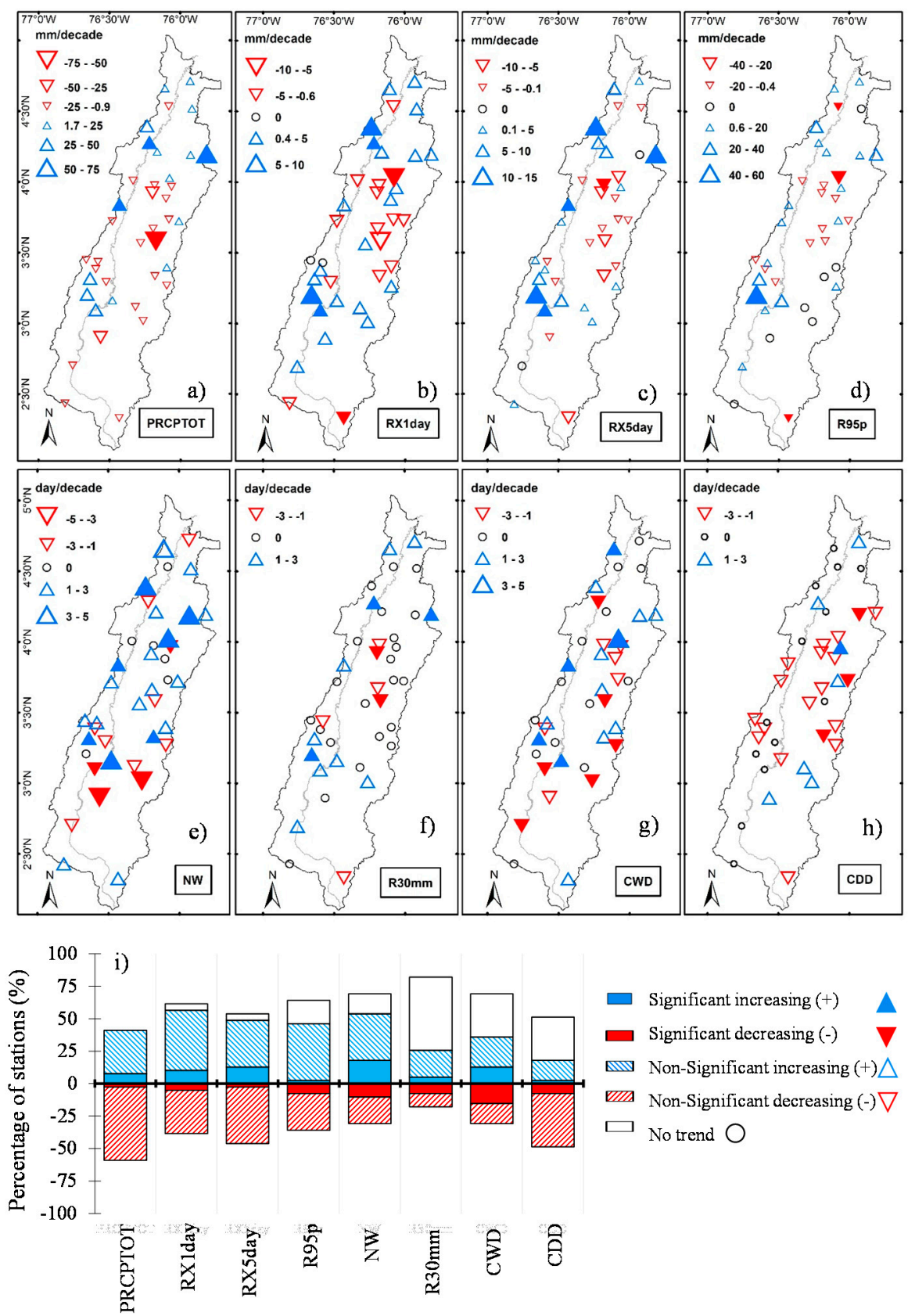

Figure A2. Spatial distribution of decadal trends for March-April-May (MAM). (a) PRCPTOT, (b) RX1day, (c) RX5day, (d) R95p, (e) NW, (f) R30mm, (g) CWD (h) CDD and (i) Percentage of stations with positive, negative and no change trends, out of the total stations examined over the Cauca River High Basin over the 1970-2013 period. Upward (downward) triangles refer to positive (negative) trends. Saturated triangles indicate trends significant at the $5 \%$ level and circles indicate no change trends. 

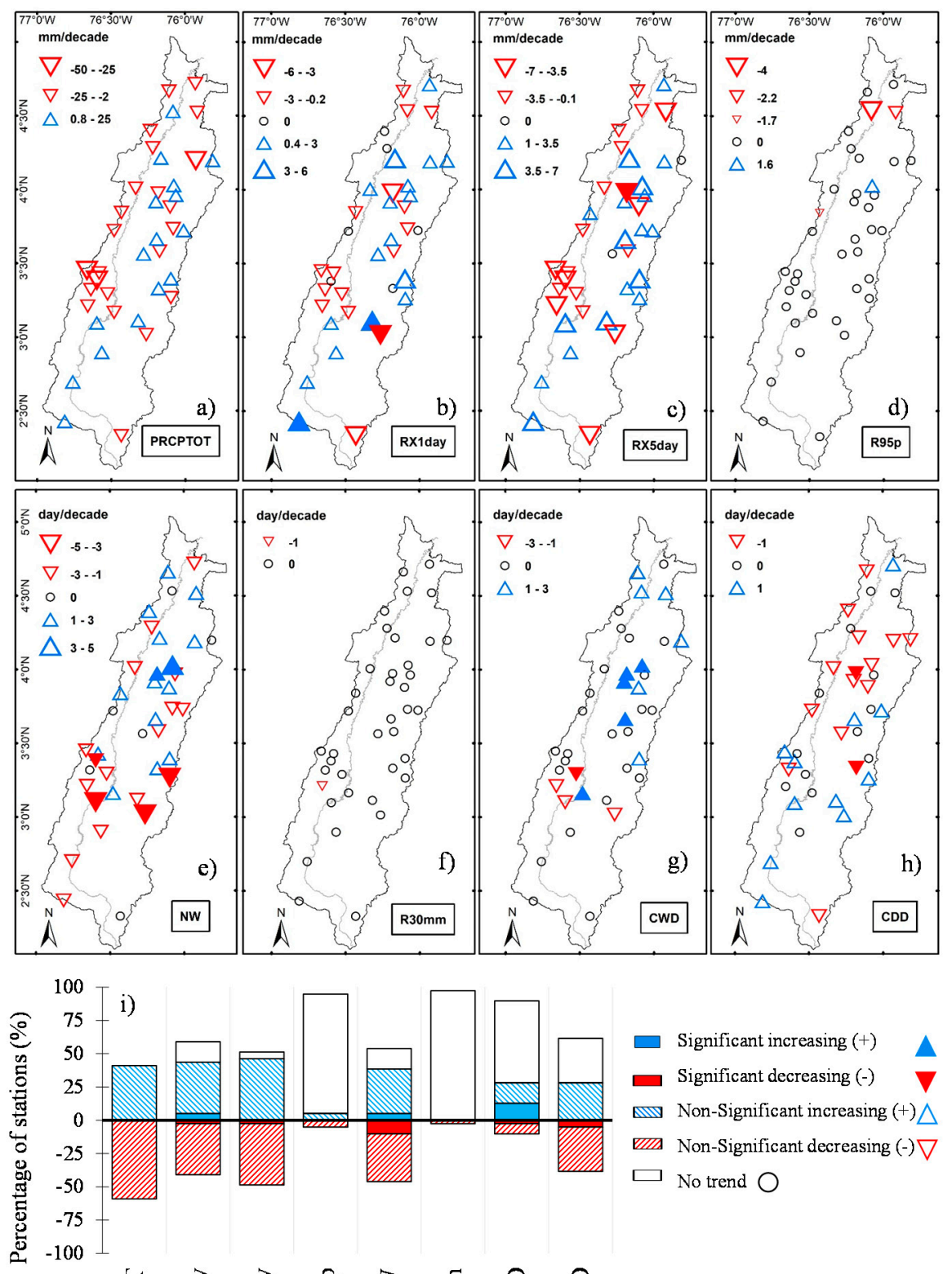

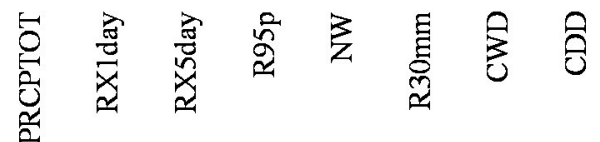

Figure A3. Spatial distribution of decadal trends for June-July-August (JJA). (a) PRCPTOT, (b) RX1day, (c) RX5day, (d) R95p, (e) NW, (f) R30mm, (g) CWD (h), CDD and (i) Percentage of stations with positive, negative and no change trends, out of the total stations examined over the Cauca River High Basin over the 1970-2013 period. Upward (downward) triangles refer to positive (negative) trends. Saturated triangles indicate trends significant at the $5 \%$ level and circles indicate no change trends. 


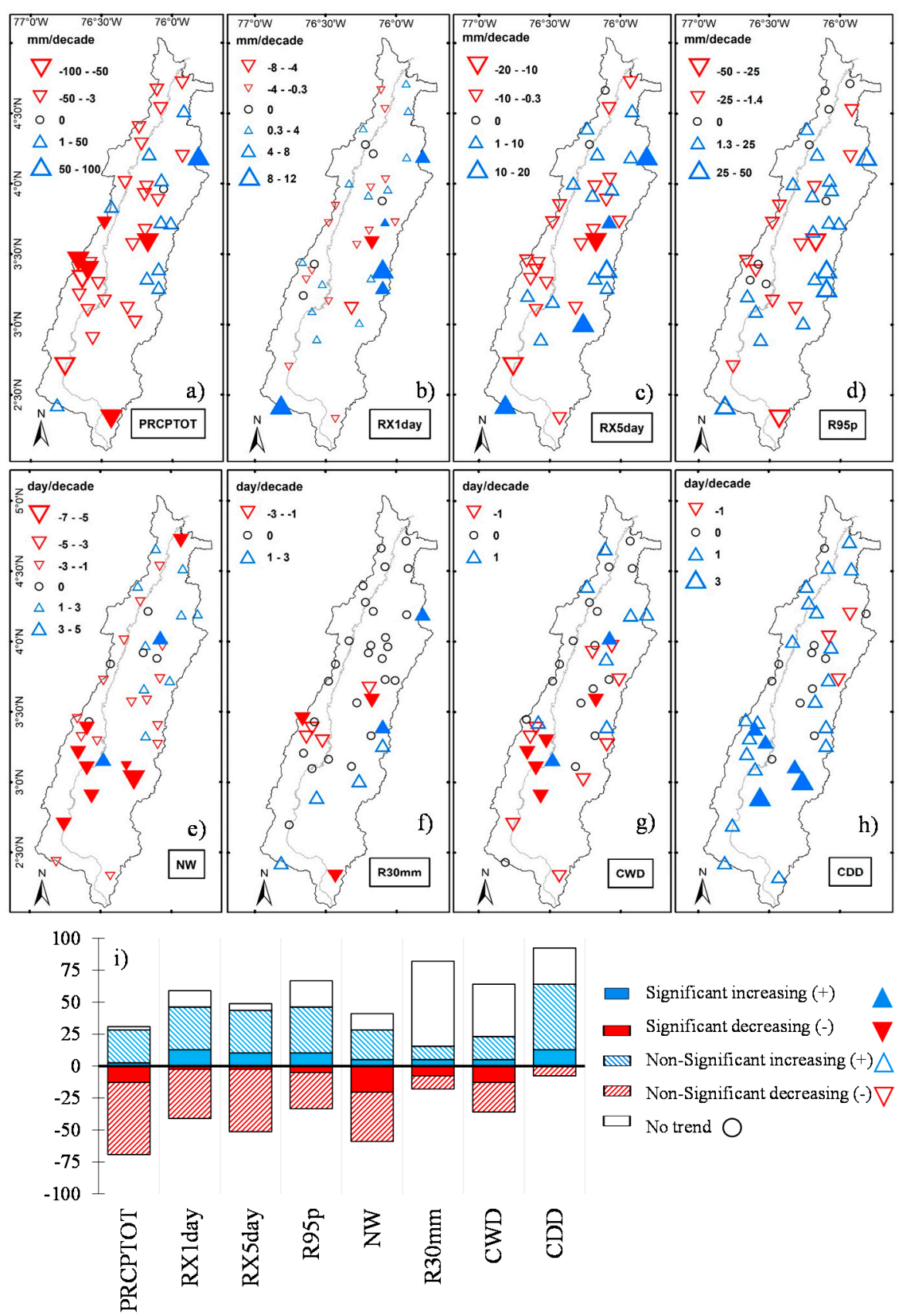

Figure A4. Spatial distribution of decadal trends for September-October-November (SON). (a) PRCPTOT, (b) RX1day, (c) RX5day, (d) R95p, (e) NW, (f) R30mm, (g) CWD, (h) CDD and (i) Percentage of stations with positive, negative and no change trends, out of the total stations examined over the Cauca River High Basin over the 1970-2013 period. Upward (downward) triangles represent positive (negative) trends. Saturated triangles indicate trends significant at the $5 \%$ level and circles indicate no change trends. 

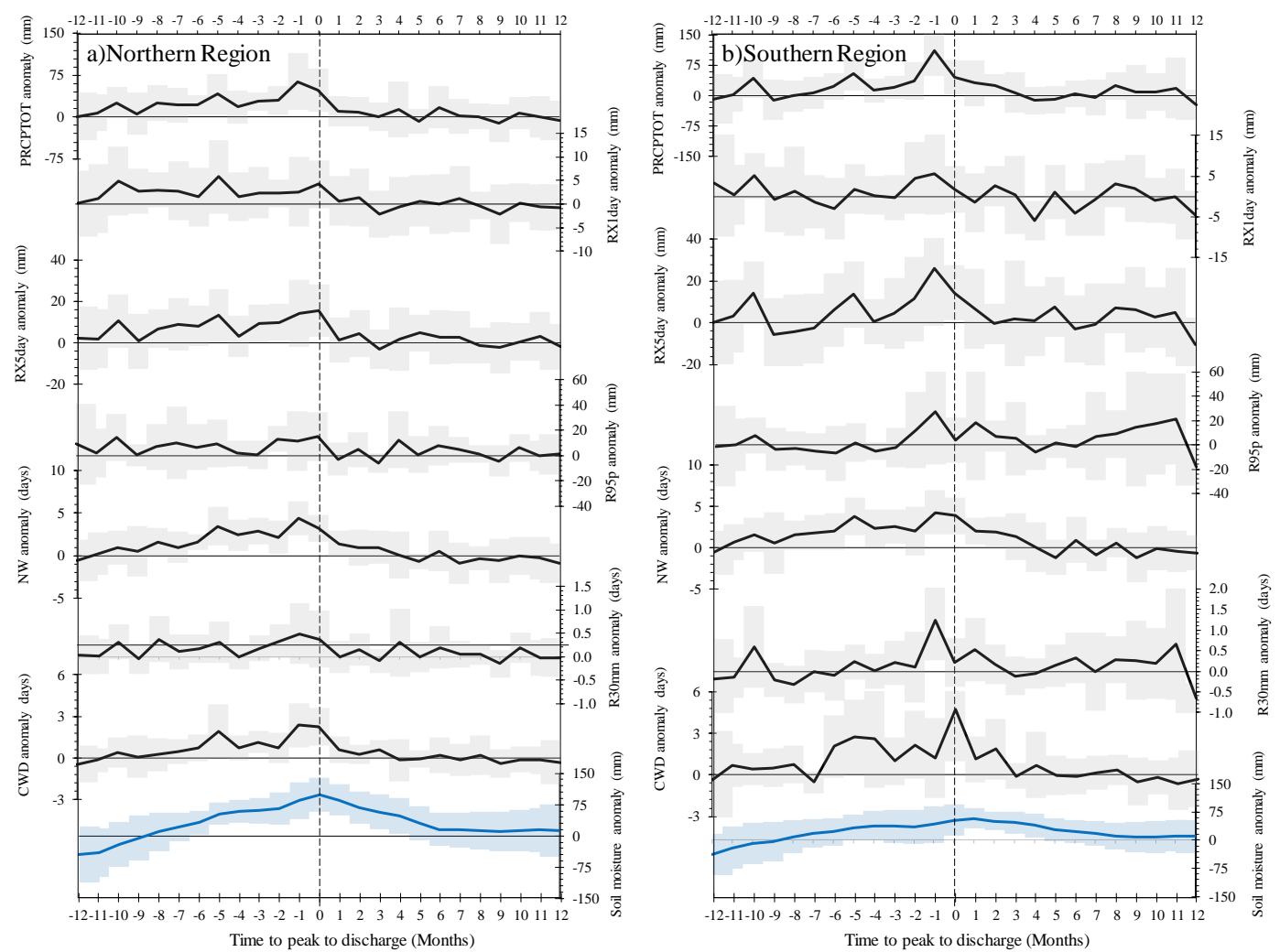

Figure A5. Index anomalies over northern (a) and southern (b) regions for PRCPTOT, RX1day, RX5day, R95, NW, R30mm, CDW, and soil moisture Niño 3.4 for floods that occurred under La Niña conditions $(n=11)$ in relation to the time of the month with a peak discharge. The mean (line) and $95 \%$ confidence interval (shaded bands) are shown for each index. The vertical dotted lines refer to the peak of discharge; horizontal lines denote a zero anomaly for each index calculated.

\section{References}

1. Smyth, C.G.; Royle, S.A. Urban landslide hazards: Incidence and causative factors in Niteroi, Rio de Janeiro state, Brazil. Appl. Geogr. 2000, 20, 95-117. [CrossRef]

2. Poveda, G. La Hidroclimatología de Colombia: Una Síntesis Desde la Escala Inter-Decadal Hasta la Escala Diurna. Rev. la Acad. Colomb. Ciencias 2004, XXVIII, 201-222.

3. Poveda, G.; Álvarez, D.M.; Rueda, Ó.A. Hydro-climatic variability over the Andes of Colombia associated with ENSO: A review of climatic processes and their impact on one of the Earth's most important biodiversity hotspots. Clim. Dyn. 2011, 36, 2233-2249. [CrossRef]

4. World Bank. El cambio climático y los fenómenos de El Niño y La Niña. In Análisis de la gestión del riesgo de desastres en Colombia: Un aporte para la construcción de políticas públicas; Campos, G., Holm-Nielsen, N., Díaz, C., Rubiano, D., Costa, C., Ramírez, F., Dickson, E., Eds.; World Bank: Bogotá, Colombia, 2012; Volume 2, pp. 50-51.

5. Hoyos, I.; Baquero-Bernal, A.; Jacob, D.; Rodríguez, B.A. Variability of extreme events in the Colombian Pacific and Caribbean catchment basins. Clim. Dyn. 2013, 40, 1985-2003. [CrossRef]

6. Enciso, A.; Carvajal, Y.; Sandoval, M. Hydrological analysis of historical floods in the upper valley of Cauca river (in Spanish). Ing. Y Compet. 2016, 57, 46-57.

7. Ragettli, S.; Immerzeel, W.W.; Pellicciotti, F. Contrasting climate change impact on river flows from high-altitude catchments in the Himalayan and Andes Mountains. Proc. Natl. Acad. Sci. USA 2016, 113, 9222-9227. [CrossRef] [PubMed]

8. Campozano, L.; Vázquez-Patiño, A.; Tenelanda, D.; Feyen, J.; Samaniego, E.; Sánchez, E. Evaluating extreme climate indices from CMIP $3 \& 5$ global climate models and reanalysis data sets: a case study for present climate in the Andes of Ecuador. Int. J. Climatol. 2017, 37, 363-379. 
9. Sedano, K.; Carvajal, Y.; Ávila, Á. Analysis of the aspects which increase the risk of floods in Colombia (in Spanish). Luna Azul 2013, 37, 219-238.

10. Hoyos, N.; Escobar, J.; Restrepo, J.; Arango, A.; Ortiz, J. Impact of the 2010-2011 La Niña phenomenon in Colombia, South America: The human toll of an extreme weather event. Appl. Geogr. 2013, 39, 16-25. [CrossRef]

11. Skansi, M.; Brunet, M.; Sigró, J.; Aguilar, E.; Arevalo, G.; Bentancur, O.; Castellón, G.; Correa, A.; Jácome, H.; Malheiros, R.; et al. Warming and wetting signals emerging from analysis of changes in climate extreme indices over South America. Glob. Planet. Change 2013, 100, 295-307. [CrossRef]

12. Mallakpour, I.; Villarini, G. The changing nature of flooding across the central United States. Nat. Clim. Chang. 2015, 5, 250-254. [CrossRef]

13. Ávila, A.; Justino, F.; Wilson, A.; Bromwich, D.; Amorim, M. Recent precipitation trends, flash floods and landslides in southern Brazil. Environ. Res. Lett. 2016, 11, 1-13. [CrossRef]

14. Donat, M.G.; Lowry, A.L.; Alexander, L.V.; O'Gorman, P.A.; Maher, N. More extreme precipitation in the world's dry and wet regions. Nat. Clim. Chang. 2016, 6, 508-513. [CrossRef]

15. Debortoli, N.; Camarinha, P.; Marengo, J.; Rodrigues, R. An index of Brazil's vulnerability to expected increases in natural flash flooding and landslide disasters in the context of climate change. Nat. Hazards 2017, 86, 557-582. [CrossRef]

16. Marengo, J.; Valverde, M.; Obregon, G. Observed and projected changes in rainfall extremes in the Metropolitan Area of São Paulo. Clim. Res. 2013, 57, 61-72. [CrossRef]

17. Duan, W.; He, B.; Takara, K.; Luo, P.; Hu, M.; Alias, N.E.; Nover, D. Changes of precipitation amounts and extremes over Japan between 1901 and 2012 and their connection to climate indices. Clim. Dyn. 2015, 45, 2273-2292. [CrossRef]

18. Wang, R.; Li, C. Spatiotemporal analysis of precipitation trends during 1961-2010 in Hubei province, central China. Theor. Appl. Climatol. 2015, 124, 385-389. [CrossRef]

19. Tanoue, M.; Hirabayashi, Y.; Ikeuchi, H. Global-scale river flood vulnerability in the last 50 years. Sci. Rep. 2016, 6, 36021. [CrossRef] [PubMed]

20. Chadwick, R.; Good, P.; Martin, G.; Rowell, D. Large rainfall changes consistently projected over substantial areas of tropical land. Nat. Clim. Chang. 2016, 6, 177-181. [CrossRef]

21. Fischer, E.M.; Knutti, R. Observed heavy precipitation increase confirms theory and early models. Nat. Clim. Chang. 2016, 6, 986-991. [CrossRef]

22. Zhou, X.; Bai, Z.; Yang, Y. Linking trends in urban extreme rainfall to urban flooding in China. Int. J. Climatol. 2017, 37, 4586-4593. [CrossRef]

23. Cardona, F.; Ávila, Á.; Carvajal, Y.; Jiménez, H. Trends into rainfall time series of two Andes basins of Valle del Cauca (in Spanish). Tecnológicas 2014, 17, 85-95.

24. Armenteras, D.; Rodríguez, N.; Retana, J.; Morales, M. Understanding deforestation in montane and lowland forests of the Colombian Andes. Reg. Environ. Chang. 2011, 11, 693-705. [CrossRef]

25. Restrepo, J.; Kettner, A.; Syvitski, J. Recent deforestation causes rapid increase in river sediment load in the Colombian Andes. Antrhropocene 2015, 10, 13-28. [CrossRef]

26. Aguilar, E.; Peterson, T.C.; Obando, P.R.; Frutos, R.; Retana, J.A.; Solera, M.; Soley, J.; García, I.G.; Araujo, R.M.; Santos, A.R.; et al. Changes in precipitation and temperature extremes in Central America and northern South America, 1961-2003. J. Geophys. Res. 2005, 110, 1-15. [CrossRef]

27. Puertas, O.; Carvajal, Y.; Quintero, M. Study of monthly rainfall trends in the upper and middle Cauca River Basin, Colombia. Dyna 2011, 169, 112-120.

28. El Río Cauca en su valle alto; CVC: Santiago de Cali, Colombia, 2007; ISBN 9789588332109.

29. Pérez, M.A.; Peña, M.R.; Alvarez, P. Agro Industria Cañera y uso del agua: análisis crítico en el contexto de la política de agrocombustibles en Colombia. Ambient. Soc. 2011, XIV, 153-178.

30. Ávila, Á.; Carvajal, Y. Agrofuels and Food Sovereignty in Colombia (in Spanish). Cuad. Geogr. 2015, 24, 43-60.

31. Berrío, J.C.; Hooghiemstra, H.; Marchant, R.; Rangel, O. Late-glacial and Holocene history of the dry forest area in the south. J. Quat. Sci. 2002, 17, 667-682. [CrossRef]

32. Poveda, G.; Waylen, P.R.; Pulwarty, R.S. Annual and inter-annual variability of the present climate in northern South America and southern Mesoamerica. Palaeogeogr. Palaeoclimatol. Palaeoecol. 2006, 234, 3-27. [CrossRef] 
33. Jaramillo, L.; Poveda, G.; Mejía, J.F. Mesoscale Convective Systems and other Precipitation Features over the Tropical Americas and Surrounding Seas as seen by TRMM. Int. J. Climatol. 2000, 37, 380-397. [CrossRef]

34. Poveda, G.; Mesa, O.J. Feedbacks between hydrological processes in tropical South America and large-scale ocean-atmospheric phenomena. J. Clim. 1997, 10, 2690-2702. [CrossRef]

35. Poveda, G.; Salazar, L.F. Annual and interannual (ENSO) variability of spatial scaling properties of a vegetation index (NDVI) in Amazonia. Remote Sens. Environ. 2004, 93, 391-401. [CrossRef]

36. Poveda, G.; Mesa, O.J.; Salazar, L.F.; Arias, P.A.; Moreno, H.A.; Vieira, S.C.; Agudelo, P.A.; Toro, V.G.; Alvarez, J.F. The Diurnal Cycle of Precipitation in the Tropical Andes of Colombia. Mon. Weather Rev. 2005, 133, 228-241. [CrossRef]

37. Wang, X.; Feng, Y. RHtestV3 User Manual, Climate Research Division, Atmospheric Science and Technology Directorate; Science and Technology Branch, Environment Canada: Downsvies, ON, Canada, 2009; p. 29.

38. Zhang, X.; Yang, F. RClimDex_User Manual; Climate Research Branch Environment Canada: Toronto, ON, Canada, 2004; p. 22.

39. Zhang, X.; Alexander, L.; Hegerl, G.; Jones, P.; Tank, A.; Peterson, T.; Trewin, B.; Zwiers, F. Indices for monitoring changes in extremes based on daily temperature and precipitation data. Wiley Interdiscip. Rev. Clim. Chang. 2011, 2, 851-870. [CrossRef]

40. Santos, M.; Fragoso, M.; Santos, J. Regionalization and susceptibility assessment to daily precipitation extremes in mainland Portugal. Appl. Geogr. 2017, 86, 128-138. [CrossRef]

41. Wu, C.; Huang, G. Changes in heavy precipitation and floods in the upstream of the Beijiang River basin, South China. Int. J. Climatol. 2015, 35, 2978-2992. [CrossRef]

42. Sillmann, J.; Kharin, V.; Zwiers, W.; Zhang, X.; Bronaugh, D. Climate extremes indices in the CMIP5 multimodel ensemble: Part 2. Future climate projections. J. Geophys. Res. Atmos. 2013, 118, 2473-2493. [CrossRef]

43. Kendall, M. Rank Correlation Methods, 4th ed.; Charles Griffin: London, UK, 1990; p. 160. ISBN 0852641990.

44. Mann, H.B. Nonparametric tests against trend. Econometrica 1945, 13, 245-259. [CrossRef]

45. Liu, M.; Xu, X.; Sun, A.; Wang, K.; Liu, W.; Zhang, X. Is southwestern China experiencing more frequent precipitation extremes? Environ. Res. Lett. 2014, 9, 1-15. [CrossRef]

46. Sen, P. Estimates of the Regression Coefficient Based on Kendall's Tau. J. Am. Stat. Assoc. 1968, 63, 1379-1389. [CrossRef]

47. Yue, S.; Pilon, P.; Cavadias, G. Power of the Mann-Kendall and Spearman's rho tests for detecting monotonic trends in hydrological series. J. Hydrol. 2002, 259, 254-271. [CrossRef]

48. New, M.; Hewitson, B.; Stephenson, D.; Tsiga, A.; Kruger, A.; Manhique, A.; Gomez, B.; Coelho, C.; Masisi, D.; Kululanga, E.; et al. Evidence of trends in daily climate extremes over southern and west Africa. J. Geophys. Res. Atmos. 2006, 111, 1-11. [CrossRef]

49. Poveda, G.; Velez, J.; Mesa, O.; Hoyos, C.; Mejía, F.; Barco, O.; Correa, P. Influencia de fenómenos macroclimáticos sobre el ciclo anual de la hidrología colombiana: cuantificación lineal, no lineal y percentiles probabilísticos. Meteorol. Colomb. 2002, 6, 121-130.

50. Ávila, Á.; Carvajal, Y.; Gutiérrez, S. El Niño and La Niña analysis influence in the monthly water supply at Cali River basin (in Spanish). Tecnura 2014, 18, 120-133.

51. Morán-Tejeda, E.; Bazo, J.; López-Moreno, J.I.; Aguilar, E.; Azorín-Molina, C.; Sanchez-Lorenzo, A.; Martínez, R.; Nieto, J.J.; Mejía, R.; Martín-Hernández, N.; et al. Climate trends and variability in Ecuador (1966-2011). Int. J. Climatol. 2015, 11, 3839-3855. [CrossRef]

52. Vicente-Serrano, S.; Aguilar, E.; Martínez, R.; Martín-Hernández, N.; Azorin-Molina, C.; Sanchez-Lorenzo, A.; El Kenawy, A.; Tomás-Burguera, M.; Moran-Tejeda, E.; López-Moreno, J.I.; et al. The complex influence of ENSO on droughts in Ecuador. Clim. Dyn. 2016, 48, 405-427. [CrossRef]

53. Maldonado, T.; Rutgersson, A.; Alfaro, E.; Amador, J.; Claremar, B. Interannual variability of the midsummer drought in Central America and the connection with sea surface temperatures. Adv. Geosci. 2016, 42, 35-50. [CrossRef]

54. Grupo de Hi; dráulica Fluvial y Marítima. Descripción y análisis de las inundaciones históricas. In Análisis hidráulico de las crecientes históricas del Río Cauca; Ramírez, C., García, J., Bocanegra, R., Ayala, C., Ojeda, Arias., Hurtado, E., Potes, Y., Eds.; Universidad del Valle: Cali, Colombia, 2013; Volume 1, pp. 17-96.

55. Celleri, R.; Willems, P.; Buytaert, W.; Feyen, J. Space-time rainfall variability in the Paute Basin, Ecuadorian Andes. Hydrol. Process. 2007, 3327, 3316-3327. [CrossRef] 
56. Casimiro, W.; Labat, D.; Ronchail, J.; Espinoza, J.; Guyot, J. Trends in rainfall and temperature in the Peruvian Amazon-Andes basin over the last 40 years (1965-2007). Hydrol. Process. 2012, 27, 2944-2957. [CrossRef]

57. Cuartas, D.; Caicedo, D.; Ortega, D.; Cardona, F.; Carvajal, Y.; Mendez, F. Spatial and temporal trends of extreme climate events in geographical valley of Cauca River (in Spanish). Actual. Divulg. Científica 2017, 20, 267-278.

58. Setiawan, A.; Lee, W.; Rhee, J. Spatio-temporal characteristics of Indonesian drought related to El Niño events and its predictability using the multi-model ensemble. Int. J. Climatol. 2017, 37, 4700-4719. [CrossRef]

59. Munoz, S.; Dee, S. El Niño increases the risk of lower Mississippi River flooding. Sci. Rep. 2017, 7, 1772. [CrossRef] [PubMed]

60. Ndehedehe, C.E.; Awange, J.L.; Agutu, N.O.; Okwuashi, O. Changes in hydro-meteorological conditions over tropical West Africa (1980-2015) and links to global climate. Glob. Planet. Change 2018, 162, 321-341. [CrossRef]

61. Welhouse, L.J.; Lazzara, M.A.; Keller, L.M.; Tripoli, G.J.; Hitchman, M.H. Composite analysis of the effects of ENSO events on Antarctica. J. Clim. 2016, 29, 1797-1808. [CrossRef]

62. Sheffield, J.; Goteti, G.; Wood, E.; New, M.; Hulme, M.; Jones, P.; Sheffield, J.; Goteti, G.; Wood, E.; Chaney, N.; et al. Development of a 50-Year High-Resolution Global Dataset of Meteorological Forcings for Land Surface Modeling. J. Clim. 2006, 19, 3088-3111. [CrossRef]

63. Hirahara, S.; Ishii, M.; Fukuda, Y. Centennial-Scale Sea Surface Temperature Analysis and Its Uncertainty. J. Clim. 2014, 28, 57-75. [CrossRef]

64. Fan, Y.; van den Dool, H. Climate Prediction Center global monthly soil moisture data set at $0.5^{\circ}$ resolution for 1948 to present. J. Geophys. Res. D Atmos. 2004, 109, 1-8. [CrossRef]

65. Armenteras, D.; Retana, J.; Molowny, R.; Roman, R.; Gonzalez, F.; Morales, M. Characterising fire spatial pattern interactions with climate and vegetation in Colombia. Agric. For. Meteorol. 2011, 151, 279-289. [CrossRef]

66. Córdoba-Machado, S.; Palomino-Lemus, R.; Gámiz-Fortis, S.R.; Castro-Díez, Y.; Esteban-Parra, M.J. Seasonal streamflow prediction in Colombia using atmospheric and oceanic patterns. J. Hydrol. 2016, 538, 1-12. [CrossRef] 